\title{
10. Building Capacity for Policy Implementation
}

\section{Anne Tiernan, Centre for Governance and Public Policy, Griffith University}

\section{Introduction}

In Australia and internationally, the discourse of 'declining policy capacity' is pervasive. Politicians, practitioners and scholars have expressed concern about the ability of the public service to support policy processes through its analysis, advisory and service delivery functions. There is particular concern about policy implementation - about the ability and willingness of the public service to promptly deliver on government commitments and priorities, and about the extent to which policy and program design is informed by operational realities. Anxieties about the potential for 'disconnect' between policy and service delivery have been heightened by recent high-profile failures in sensitive areas of government policy. This chapter examines recent efforts by the Commonwealth and Queensland governments to build capacity for policy implementation, notably through the establishment of implementation units. It offers an assessment of their potential to address the dilemmas of implementation exposed by recent policy failures.

\section{Declining policy capacity}

Both in Australia and internationally, there is concern that governments have lost policy capacity (Parsons 2004; Peters 1996; Savoie 2003). The concept of policy capacity is complex and ambiguous, but is typically concerned with policy advising - specifically the availability of high quality information, analysis and advice to support decision-making.

Perceptions that policy capacity has declined are widespread, including in Australia (Edwards, Ayers and Howard 2003). Under a variety of labels including 'capacity', 'competency' and 'capability', concerns have been expressed about the ability of governments to make intelligent choices (Painter and Pierre 2005), to scan the environment and set strategic directions (Howlett and Lindquist 2004; Savoie 2003), to weigh and assess the implications of policy alternatives (Bakvis 2000), and to make appropriate use of knowledge in policy-making (Parsons 2004; Peters 1996). Others question the ability of existing processes and structures to ensure an appropriate flow of information, analysis and advice to decision-makers (Painter and Pierre 2005; Walter 2006), particularly around issues of policy implementation and delivery, and whether after two decades of 
almost continuous public sector reform, the public service has the requisite expertise, knowledge, skills and resources to support decision-making through its policy advising functions (Bakvis and Aucoin 2005).

Concerns about declining policy capacity have been expressed by ministers, senior public servants and scholars. Prime ministers from Australia's John Howard, to New Zealand's Helen Clark to Britain's Tony Blair have stated publicly that they have been underwhelmed, and at times let down, by advice from their bureaucratic advisers. The Australian Wheat Board (AWB), Iraq weapons intelligence and 'children overboard' controversies are recent cases in point. In Queensland, Premier Peter Beattie, has complained bitterly about the quality of advice provided to him by public service departments and agencies. Public service leaders have also expressed concern about declining policy advising skills and competencies (Briggs 2005; Podger 2002; Wintringham 2003), particularly in moments of crisis (Shergold 2004b).

Though expressed in similar terms, the discourse of declining policy capacity means different things to different people. It has become an umbrella term encompassing a variety of concerns about:

- the research, analytical and advisory skills and abilities of the public service;

- the ability of the public service to recruit and retain people with requisite knowledge, skills and experience;

- the nature of relationships between officials and political executives; and

- the policy advising role of the public service in an increasingly dynamic, pluralised and contestable environment.

Within the discourse of declining policy capacity, concerns have also been expressed about implementation and delivery, specifically:

- the ability and willingness of the public service to promptly deliver government commitments and priorities;

- the potential for policy intent to become distorted or diffused during implementation. That is, for the 'line of sight' between policy formulation and implementation to be obscured;

- the public service's ability to mobilise and coordinate around whole-of-government issues and priorities; and

- the potential for unanticipated or unintended consequences to flow from government policy interventions.

Such concerns have sparked a more general renewal of interest in policy implementation - a much neglected topic in policy studies (Barrett 2004). The Blair government in Britain is frequently credited with spearheading this agenda, mostly tangibly through its creation of the Prime Minister's Delivery Unit (PMDU) in 2001. The PMDU is dedicated to ensuring that the government delivers on its priorities in key areas of public service provision (Smith and Richards 2006). 
A major reform effort is currently focused on enhancing the British government's capacity for policy delivery, including the requirement for regular departmental 'capability reviews' to be conducted by the PMDU. ${ }^{1}$ Implementation Units have emerged within the core executives of other jurisdictions including the Australian Commonwealth (Wanna 2006) and Queensland (Tiernan 2006). The Victorian and South Australian governments have also established implementation units recently. This suggests that there is broad interest in strengthening capacity for implementation and that significant policy transfer and learning is occurring between jurisdictions - a finding endorsed by comparative research. Lindquist (2006) notes that first ministers in each of these locations have instigated the development of new central capacities to 'advise, monitor and ensure better implementation of policy initiatives'.

The renewed focus on policy implementation has been primarily driven from the political centre. In the Commonwealth and elsewhere, implementation units are co-located with Cabinet support functions in Prime Minister's and Premiers' departments. As with much of the infrastructure supporting first ministers, they are instruments of central control, principally concerned with advancing the political interests of the incumbent leader (Peters, Rhodes and Wright 2000, p. 266).

Since their establishment in late 2003 and early 2004 respectively, the Commonwealth and Queensland implementation units have established strong central monitoring and reporting of commitments and priorities. Procedural changes to focus agency attention on implementation planning during policy development have been introduced and the units are engaged in a variety of awareness and consciousness raising initiatives - the Commonwealth much more so than its Queensland counterpart. ${ }^{2}$ Secretary of the Department of the Prime Minister and Cabinet, Dr Peter Shergold, has been an energetic champion of the Cabinet Implementation Unit, and of the utility of project management techniques in implementation planning and monitoring (see, for example, Shergold 2004; 2006b).

\section{Concerns justified: delivery failures}

Concerns about implementation capacity have been reinforced by high profile implementation and delivery failures. In Canberra, the treatment of two mentally ill Australian citizens wrongly deported by the Immigration Department became a major scandal, precipitating wide-ranging reforms to the structure and culture of the agency (Palmer 2005). The botched repatriation of the body of Australian soldier, Jake Kovco, accidentally killed in Iraq, exposed coordination difficulties in the interface between the Department of Defence and private contractors, at the cost of great hurt to the bereaved family, and major embarrassment to the Defence Minister and the government. In Queensland, a litany of delivery 
problems has plagued the Beattie Labor government during its third term, most seriously the 'crisis' in the State's public hospital system (Tiernan 2006). These cases have served as ominous reminders to politicians and public administrators alike of the serious political costs and consequences of implementation failure. As Peter Shergold noted recently:

Poor delivery - such as inadequate service levels, lack of timeliness or burdensome regulatory processes - risks public dissatisfaction. It can reduce trust not only in public service but in the government it serves. The quality of the implementation of government policy is central to community support for the institutions of democratic governance (Shergold 2006b, p. 1).

Much of the focus of the Australian implementation units has been on ensuring delivery issues are planned and addressed in new policy areas. The problems and failures afflicting the two governments have occurred in established service delivery systems. In the Immigration and Queensland hospitals cases, governments responded by establishing independent inquiries, including in the Queensland case, a royal commission. As well as providing forums for investigating the factors that led to the events in question, the reports of these inquiries have generated useful blueprints for reform and change. They have highlighted a serious disconnect between policy and service delivery - the classic implementation deficit identified by Pressman and Wildavsky (1973) in their seminal study of implementation failure.

In Queensland, consultant Peter Forster (2005) who led the independent review of public hospitals, was particularly critical of central agency and head office officials for failing to appreciate and address systemic problems of under-funding, workload issues, and the difficulties of recruiting and retaining appropriately qualified staff to work in the state's public hospital system. Forster (2005) describes a major 'expectation gap' between what politicians and the public expect can be delivered and what service systems are actually capable of. Managing public expectations is an invidious and likely insoluble implementation dilemma for politicians, as recent criticism of the Commonwealth and Queensland government responses to the Cyclone Larry disaster have again demonstrated. Despite a swift and focused emergency response to widespread damage wreaked by the cyclone, and the difficulties of establishing services in the absence of electricity and transport access, governments were criticised by some locals, frustrated by delays in gaining access to relief supplies and funds. Their complaints were amplified through the broadcast media - a young woman's anger at perceived inaction of 'bureaucrats', broadcast to an attentive national audience.

The Immigration and Queensland hospitals cases also highlight the difficulties of ensuring that operational realities are reflected in policy advice and 
decision-making, though it is interesting to note that both have been identified primarily as public service failures - as failures of analysis and persuasion (see Briggs 2005; Shergold 2006b), rather than failures on the part of policy-makers to understand systemic problems and direct energy, attention and resources towards addressing them before they escalated.

In the wake of these controversies, the Australian and Queensland governments have initiated wholesale changes to affected departments. In Immigration and in Queensland Health, the entire senior leadership teams were replaced, and the organisations were radically restructured. There have been major funding injections, and agency-based implementation units are bolstering the commitment to 'fix' the identified problems. Strong central monitoring and reporting arrangements have been established, including requirements to provide regular reports to Parliament. ${ }^{3}$

But rather than building local capacity, the appointment of significant numbers of central agency staff to leadership positions in agencies like Immigration and Queensland Health raises questions about the value placed on content knowledge and service delivery expertise. Though perhaps understandable in an increasingly personalised governance context, there are tensions between building capacity for implementation and parachuting it in. It may further undermine confidence in agencies already regarded as having failed in their duties to government and the community. In both cases, delivery problems have persisted after some initial blood-letting; agencies and their responsible ministers remain in the media spotlight, as new leaders try to bed down hastily devised political 'fixes' and confront the very genuine complexities of large-scale system reform.

These developments reflect the inherent tensions between 'the normative expectations of managerial control of policy implementation processes' (Barrett 2004 , p. 260) and the realities of implementation in a networked and highly politicised service delivery context. Tiernan (2006) notes the predominance of a 'top-down' view of implementation in the development of implementation units and their monitoring strategies, especially in areas that have caused political embarrassment. Barrett (2004) and Hudson (2006) observe a similarly top-down orientation to implementation in the British context, noting 'there is a lack of recognition of the time and resources involved in achieving the organisational capacity to achieve effective change' (Barrett 2004, p. 260).

Political pressure to quickly address problems and failures in sensitive areas of public policy may have perverse unintended consequences, potentially embedding new and different implementation challenges down the track. For example, Barrett (2004, p. 260) describes how 'top down coercive pressure to meet prescribed targets' has 'led to the skewing of service priorities' (in this case hospital waiting lists), and 'even the manipulation of figures for the fear of the consequences of failure'. Shergold, however, is unapologetic about the need for 
the focus on implementation and delivery to be driven centrally. He argues that 'better implementation must consciously be driven from the top down', while simultaneously acknowledging that policy prepared without the experience of those who deliver it 'is almost certainly policy that will be poorly designed and difficult to implement' (Shergold 2006b, p. 3). Reconciling these competing imperatives would seem to be the key challenge facing governments in building capacity for policy implementation.

What role will implementation units play in this agenda, and how and in what ways will their establishment help to address the problem of implementation capacity in contemporary government? What are the prospects of addressing the capacity problem through the establishment of implementation units? The papers contributed to the special issue of the Journal of Comparative Policy Analysis (JCPA) on the emergence of implementation units demonstrate clearly that some progress has been made. Central units are playing leadership roles in promoting and raising awareness of implementation at the 'front end' - during policy development and design, though there are issues about their capacity to do so. As fairly small units, whose work is closely linked to the strictures of the Cabinet timetable, and driven by the priorities of the first minister, central implementation units have limited capacity to undertake the kind of outreach activities that would help to build capacity for implementation across government. Peter Shergold (2006b, p. 3) describes these functions as being about 'learning by doing and then spreading the learning'.

The Immigration and Queensland hospitals controversies suggest that if the goal of the new focus on implementation is capacity building, a more constructive role for central units may be in helping promote better understandings of implementation issues and challenges, particularly among decision-makers. There is also an important role to be played in assisting agencies to more effectively communicate the complex realities of translating decisions into actionable programs to policy-makers. Greater engagement with the literature on policy implementation and the policy-action relationship (Barrett 2004) could be a useful first step, yet Lindquist (2006) reports there has been limited engagement with the implementation literature in the design and development of implementation units. In addition to their enthusiasm for project management techniques, those interested in building capacity for policy implementation would do well to revisit the scholarship and adapt some of its learnings to contemporary practice. 


\section{References}

Bakvis, H. 2000, 'Rebuilding policy capacity in the era of the fiscal dividend: A report from Canada', Governance, Vol. 13, No. 1, January, pp. 71-103.

Bakvis H. and Aucoin P. 2005, 'Public Service Reform and Policy Capacity: Recruiting and Retaining the Best and the Brightest? in M. Painter and J. Pierre (eds.) Challenges to State Policy Capacity, Palgrave Macmillan, Houndmills, Basingstoke, pp 185-204.

Barrett, S. 2004, 'Implementation studies: time for a revival?' Public Administration, Vol. 82, No. 2, pp. 249-262.

Briggs, Lynelle 2005, 'A Passion for Policy?' paper presented Wednesday 29 June 2005 as part of the ANZSOG/ANU Public Lecture Series 2005.

Edwards, M., Ayers, R. and Howard, C. 2003, Public Service Leadership: Emerging Issues, APSC.

Howlett, Michael and Lindquist, Evert 2004, 'Policy Analysis and Governance: Analytical and Policy Styles in Canada', Journal of Comparative Policy Analysis, Vol. 6, No. 3, 225 - 249, December.

Forster, P. 2005, Queensland Health Systems Review Final Report, Queensland Government, September 2005.

Lindquist, E.A. 2006, 'Organising for policy implementation: the emergence and role of Implementation Units in policy design and oversight', Journal of Comparative Policy Analysis, Vol 8, No. 4, December, p 421.

Painter, M. and Pierre, J. 2005, 'Unpacking policy capacity: issues and themes'. In Painter, M. and Pierre, J. (eds.) Challenges to State Policy Capacity: Global Trends and Comparative Perspectives, Palgrave Macmillan, Basingstoke.

Palmer, Mick 2005, Inquiry into the Circumstances of the Immigration Detention of Cornelia Rau, Commonwealth of Australia, July 2005.

Parsons, W. 2004, 'Not just steering but weaving: relevant knowledge and the craft of building policy capacity and coherence', Australian Journal of Public Administration. Vol. 63 (1), March, pp. 43-57.

Peters, B.G. 1996, The Policy Capacity of Government. Canadian Centre for Management Development.

Peters, B.G., Rhodes, R.A.W. and Wright, V. 2000, 'The struggle for control' in Peters, B.G., Rhodes, R.A.W. and Wright, V (eds.) Administering the Summit: Administration of the Core Executive in Developed Countries, Macmillan, Houndmills.

Podger, Andrew 2002, 'Defining an Australian approach to the roles and values of the public service in the twenty-first century', Canberra Bulletin of Public Administration, no.104, June 2002, pp 1-5. 
Pressman, J. and Wildavsky, A. 1973, Implementation, University of California, Berkley.

Savoie, D. 2003, Strengthening the Policy Capacity of Government, Report to the Panel on the Role of Government, Research Paper Series, Vol 1, pp 239-290.

Shergold, Peter. 2006a, Pride in Public Service, Address to the National Press Club, Canberra, 15 February.

Shergold, Peter 2006b, Project Management in Public Administration, Speech delivered to ANZSOG Conference on Project Management and Organisational Change, Canberra, 22 February.

Smith, M. and Richards, D. 2006, 'Central control and policy implementation in the UK: a case study of the Prime Minister's Delivery Unit', Journal of Comparative Policy Analysis, Vol 8, No. 4, December, p. 325.

Tiernan, A. 2006, 'Working with the stock we have: the evolving role of Queensland's implementation unit', Journal of Comparative Policy Analysis, Vol 8, No. 4, December. p. 371.

Walter, James 2006, 'Ministers, Minders and Public Servants: Changing Parameters of responsibility in Australia', Australian Journal of Public Administration, Vol 65, No 3, pp 22-27.

Wanna, J. 2006, 'From Afterthought to Afterburner: Australia's Cabinet Implementation Unit', Journal of Comparative Policy Analysis, Vol 8, No. 4, December, p. 347.

\section{ENDNOTES}

l The capability review process was announced by Cabinet Secretary and Head of the Home Civil Service, Sir Gus O'Donnell, at an appearance before the House of Commons Public Administration Select Committee in October 2005. Though details are still be worked through, the departmental capability reviews will focus explicitly on 'the underlying capability issues that impact on effective delivery'. For more information see O'Donnell's statement at: http://www.civilservice.gov.uk/publications/html /pasc_speaking_note.asp

2 For detailed descriptions of the structure and activities of the Commonwealth and Queensland Implementation Units see Wanna (2006) and Tiernan (2006) respectively, while for a comparative assessment of these developments see Lindquist (2006).

${ }^{3}$ Immigration is due to report to Parliament in September 2006. Queensland Health must report formally on the implementation of the Health Action Plan by December 2006, but is posting regular reports on progress towards key promises on its website http://www.health.qld.gov.au/news/6mthchklist.asp 